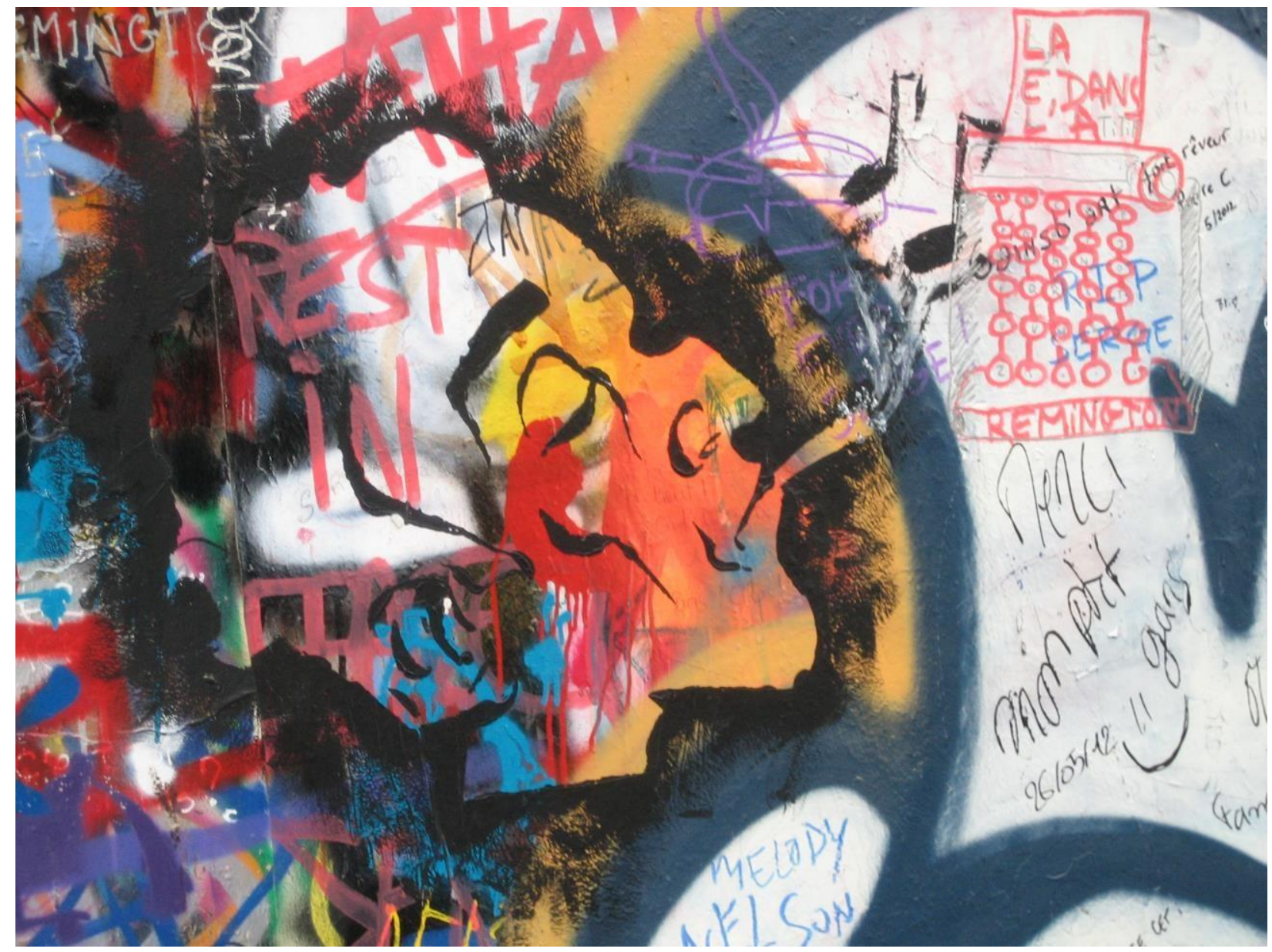

Source: Elena Siemens

\title{
Paris Wall Flowers, Moscow Wall Wars
}

Elena Siemens

"Everyone must search for what he loves, for what attracts him," Guy Debord and his associates from the Situationist International (SI) declared in the first issue of their group's journal, produced in the early 1950s (qtd. in Marcus: 175). The SI sought "a world of permanent novelty," Grail Marcus points out in his seminal Lipstick. Traces: The Secret History of the Twentieth Century (168). To reach this objective, the SI proposed two means: the "dérive," and the "detournament." The first strategy, Marcus explains, is "a drift down city streets in search of signs of attraction or repulsion," while the second is "the theft of aesthetic artifacts from their context and their diversion into contexts of one's own devise" (168). With the use of these strategies, the SI claimed, the "city would no longer be experienced as a scream of commodities and power"; instead, "it would be felt as a field of 'psychogeography" (Marcus 164). Surveying their "act actions" in his Street Art: The Graffiti Revolution, Cedar Lewisohn writes that the Situationists encouraged "people to adorn the streets with statements such as 'Free The Passions,' 'Never Work,' 'Live Without Dead Time,' and 'It's Forbidden To Forbid”' (Lewisohn 75). In addition, 
the SI "inspired people to rework or détourn metro posters, thus being an early prototype of what we now call 'subvertising"' (Lewisohn 75).

The Situationists, along with "Pop, and the ideologies of radical cultural movements such as punk," Lewisohn argues, continue to inform the work of today's street artists (Lewisohn 75). The SI has also provided inspiration for this special issue on Translating Street Art. The issue's international cast of contributors trace various contemporary expressions of "dérive" and "detournament" as found in many diverse spheres from graffiti to defaced monuments to subvertising. Following in the footsteps of Debord's legendary volume Mémoires (1957), made up of "paragraphs, sentences, phrases, or sometimes single words out of books, magazines, and newspapers," Translating Street Art incorporates poetry, photography, scholarly essays, and personal accounts (Marcus 163). Searching for their streetart artifacts, the contributors have traveled near and far. My own route took me to Moscow's Old Arbat Street, as well as Paris' Left Bank, once the Situationists' chosen playground. Marcus writes: “The SI was a group of critics; tipping back in their café chairs, they did not apologize" (Marcus 176). He quotes Debord: "Where there was fire, we carried gasoline" (176).

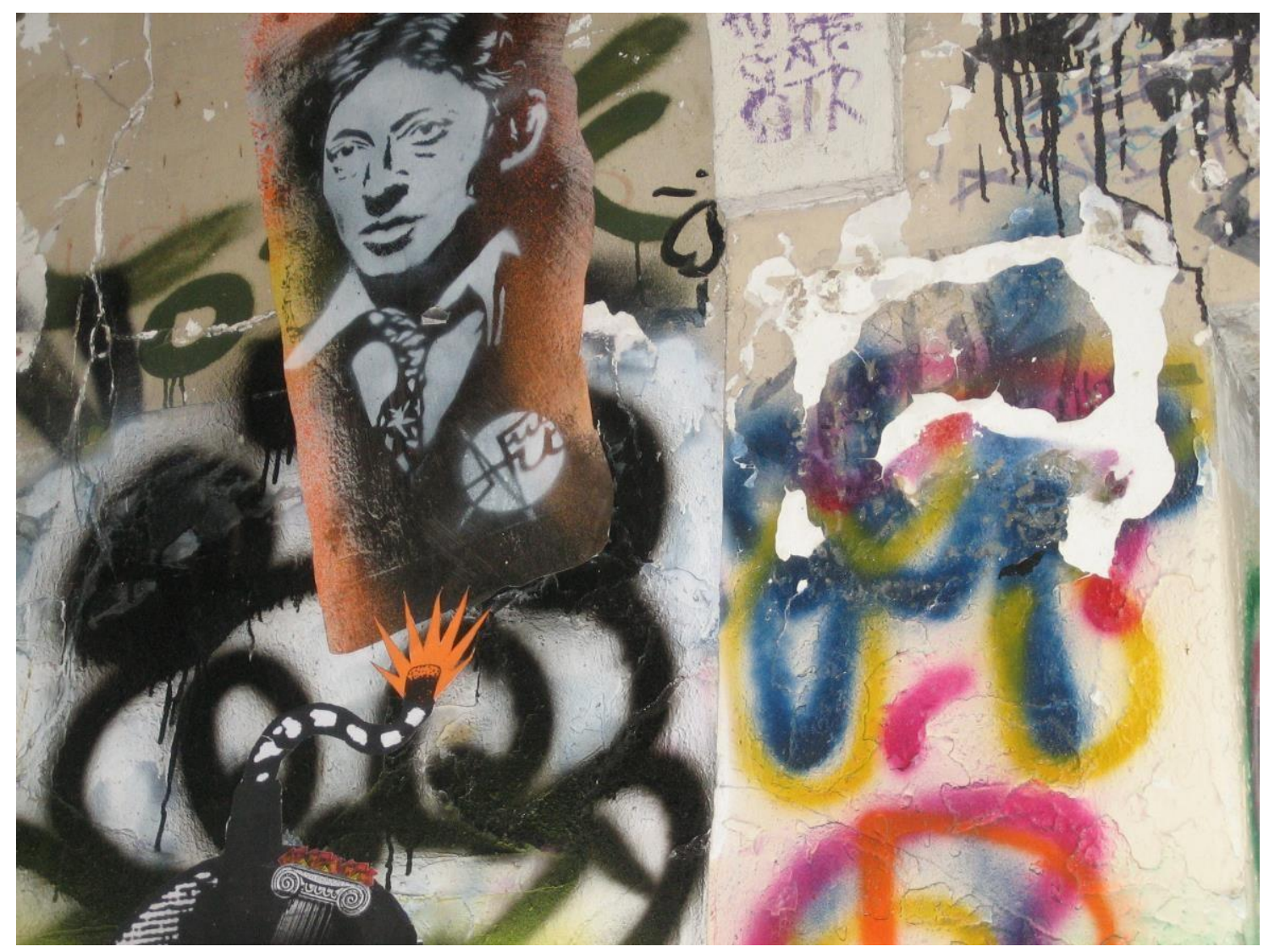

Source: Elena Siemens 


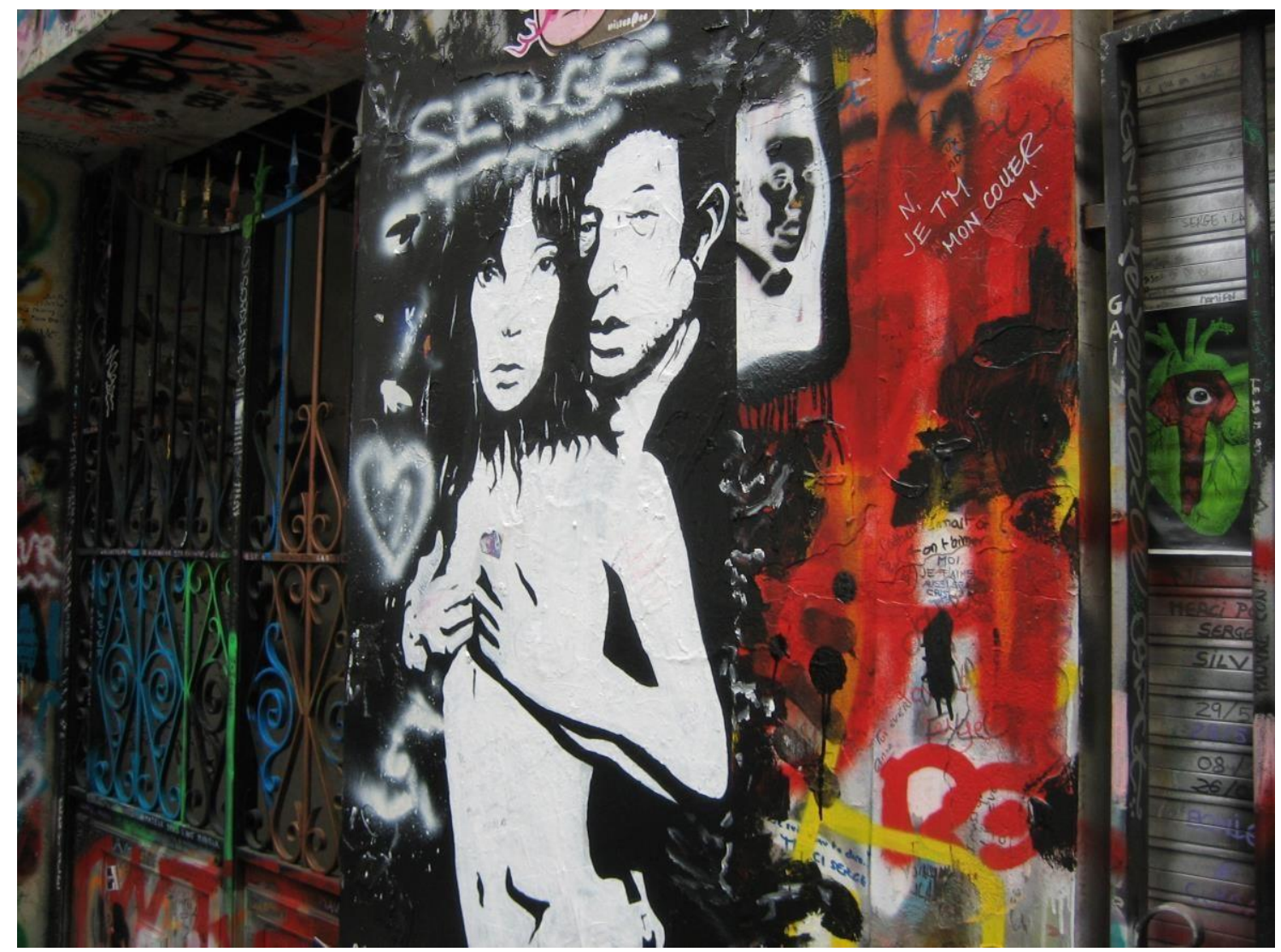

Source: Elena Siemens

At the Café de Flore souvenir shop in Paris, a helpful clerk explained how to find the nearby $7 L$ bookstore, named after its location on 7 rue de Lille. I had heard it offered an impressive selection of titles on architecture and photography, and was owned by Karl Lagerfeld himself. The clerk also suggested I take a small detour to visit the famous singer Serge Gainsbourg's house on rue de Verneuil, decorated with remarkable tribute graffiti. Compared to the Victor Tsoi Wall in Moscow, commemorating the late lead singer of the rock group Kino (Cinema), Gainsbourg's memorial was more festive, its graffiti employing a wild selection of colour. I photographed several striking portraits of Gainsbourg, and a passage from his song written in cursive against a bright pinkand-blue background:

Le soleil est rare/ Et le bonheur aussi/ L'amour s'égare/ Au long de la vie...

(The sun is rare/ and happiness too/ love drifts away/ throughout our entire lives). (Sutton)

At the 7L bookstore, the staff was equally friendly. Vincent, who manages the shop, identified the song and summed up its content. The text seemed to contradict the bright palette used by the anonymous graffiti artist. When they co-exist on the same wall, Cedar Lewisohn observes, street art and graffiti speak "different languages to different audiences" (Lewisohn 23). The Gainsbourg site in

Paris adds yet another language to this mix, that of Gainsbourg's poetry, itself a jumble of diverse references. Gainsbourg was a son of Russian Jewish emigrants, who came to France following the 
Bolshevik Revolution of 1917. His 1971 album Histoire de Melody Nelson (Melody Nelson's Story), which includes the song "La Valse de Melody" (Melody's Waltz) from my photograph, tells a story reminiscent of Vladimir Nabokov's novel Lolita (1955) - another Russian connection, and one more lucky find produced by that little detour.

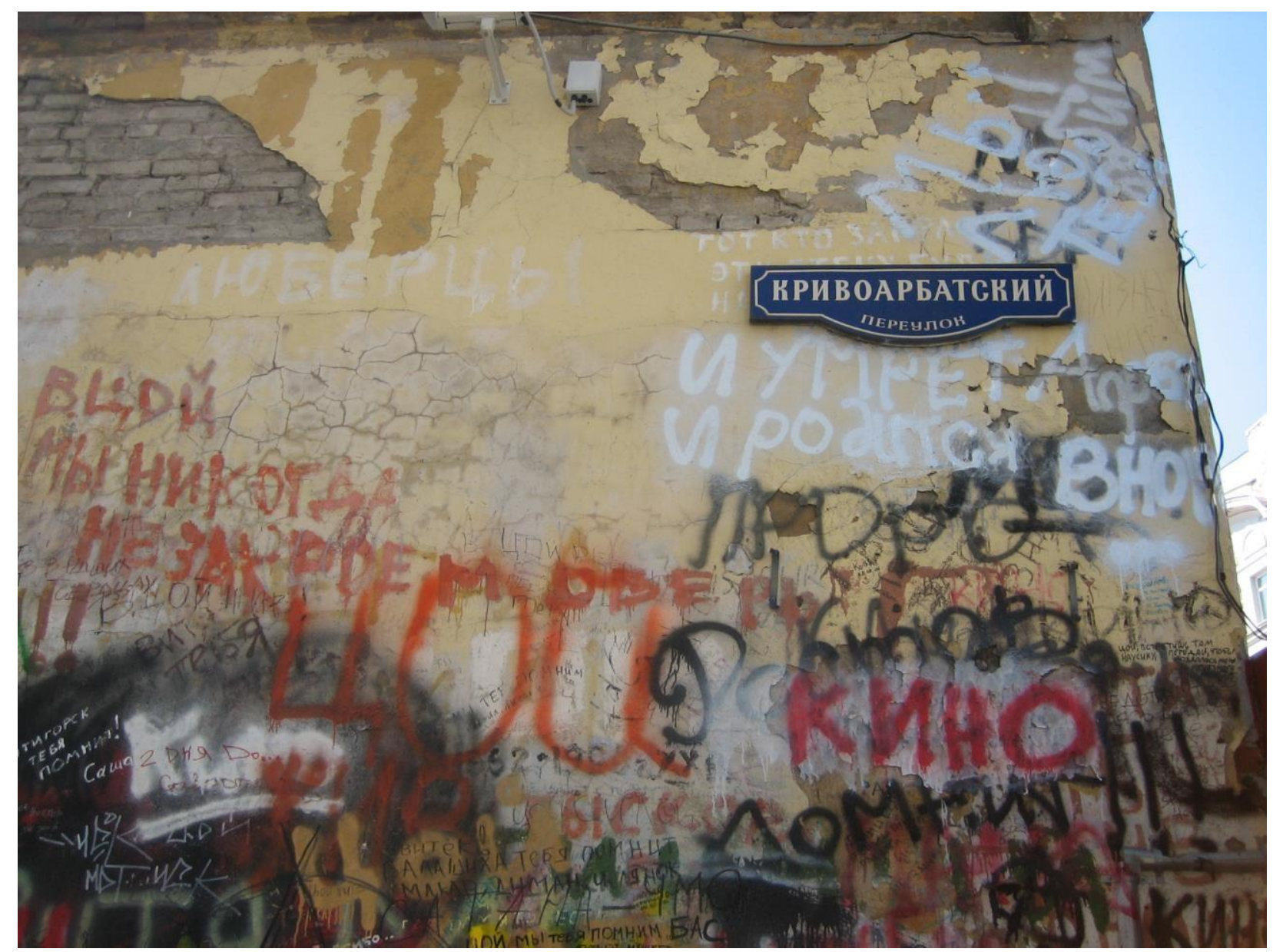

Source: Elena Siemens

In Moscow, the Tsoi Wall favours graffiti writing over the figurative language of street art. Victor Tsoi was born to a Russian mother and a Korean father. He was interested in Asian philosophy, from which he derived his cosmic imagery, as well as the notion of death as salvation. The first time I photographed it, the Tsoi Wall had a giant slogan: "V. Tsoi, We Will Never Close The Door." This line alludes to Tsoi's song "Close the Door Behind Me," featured on his album Blood Type (1988). The song reads in part:

They wait for their dinner at home, / The rain's waiting for me outside/ Close the door behind me,/ I'm leaving now.

Tsoi died in an automobile crash in 1990 at the age of twenty-eight. His first graffiti tributes, inscribed on a dilapidated wall just off Old Arbat Street, appeared on the day of his accident. A remnant of some 
TranscUlturAl, vol. 6.1 (2014), 1-10.

http://ejournals.library.ualberta.ca/index.php/TC

demolished structure, this wall quickly became the site of vigils attended by Tsoi's fans from every corner of the former Soviet Union. It is unclear why his followers have chosen this particular location for their gatherings. Tsoi's native territory was the suburban St Petersburg (then Leningrad). His songs also address those Soviet-built suburbs with their uniform tenements:

We were born in crowded apartments in new districts/ We lost our virginity fighting for love/ The clothes you made for us no longer fit us/ We've grown out of them/ and here we are to tell you/ It's our time, our turn!

Graffiti's "true potency," Nicolas Whybrow points out in Art and the City, "resides not only in its seeking out of high-risk, forbidden places in the city but high-visibility ones, too" (113). Whybrow argues that "graffiti is first an act of performance before it is one of drawing or painting (or spraying)" (114). This might explain the Tsoi Wall's incongruous location. Moscow's most prominent pedestrian street, frequented by local and foreign tourists, Old Arbat Street satisfies all of the above requirements. It offers high visibility, as well as a significant measure of risk. With its rebellious slogans and blackand-white photos of Tsoi, the decaying Tsoi Wall sticks out like a sore

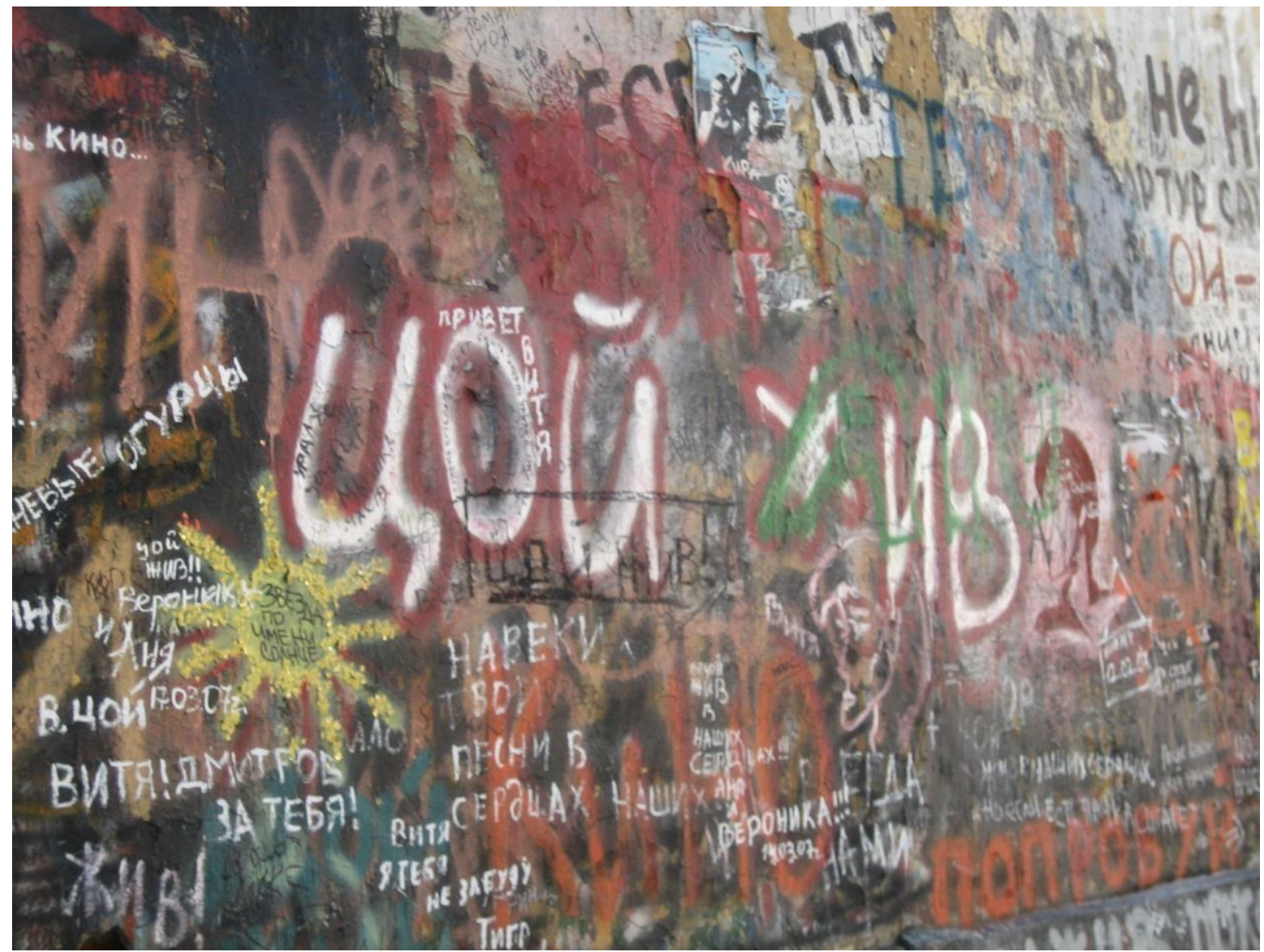

Source: Elena Siemens 
TranscUlturAl, vol. 6.1 (2014), 1-10.

http://ejournals.library.ualberta.ca/index.php/TC

thumb on Old Arbat in its affluent post-Soviet incarnation. Whybrow writes that graffiti is "an irritant, an unwanted autograph or tattoo anonymously etched on to the body of official urban culture, reminding it perhaps that 'all is not well"' (114).

"A wall has always been the best place to publish your work," the prominent UK graffiti artist Banksy states in his book of images $W$ all and Piece (Banksy 8). A play on Leo Tolstoy's War and Peace, Banksy's title is rather ambiguous. Should the word "wall" be read as synonymous with the word "war," or should it be understood as its opposite? In the book's brief introduction, Banksy sheds some light on this:

They say graffiti frightens people and is symbolic of the decline in society, but graffiti is only dangerous in the minds of three types of people: politicians, advertising executives and graffiti writers. (Banksy 8)

Banksy's own work, Lewisohn writes, "polarizes opinions" (117). His detractors see Banksy as "nothing but a graphic designer and talented self-publicist," while his fans, conversely, perceive him as "the cunning voice of dissent, staking the claim of the individual in a media-obsessed capitalist society" (Lewisohn 117). Lewisohn adds that Banksy "is given much editorial space," and "we have to be thankful" to him for introducing graffiti to "massive new audiences, and for putting the sense of fun back into the scene" (120).

The Tsoi Wall in Moscow-a call to arms-issues a challenge to the spectacular rise of consumerism on Old Arbat Street. Across from it, the officials have erected a cheerful Wall of Peace, designed to counteract the unwanted Tsoi memorial with its rebellious graffiti. In Paris, the graffiti dedicated to Gainsbourg do not seem to antagonize the city authorities. This unofficial memorial is well maintained, and it serves as a tourist attraction, although tourists must rely on the word of mouth to be able to locate it. Tourist guides tend to overlook this landmark, which, in turn, secures its counterculture status. Ironically, most guides to Moscow include at least a brief reference to the Tsoi Wall, where, The Rough Guide to Moscow points out, Tsoi's fans gather "to sing his songs and contemplate (or add to) the graffiti” (Richardson 186).

There is another important distinction between these two unofficial landmarks in Moscow and Paris. The Paris one, which relies on figurative drawings, is easier to decipher, and it invites interaction with spectators. The wall in Moscow, covered mostly with graffiti writing, is much less open to dialogue with an outsider. Almost all of the graffiti is in Russian, which creates a further obstacle to potential dialogue. The Gainsbourg site, conversely, welcomes the foreigner. While featuring some tributes in 


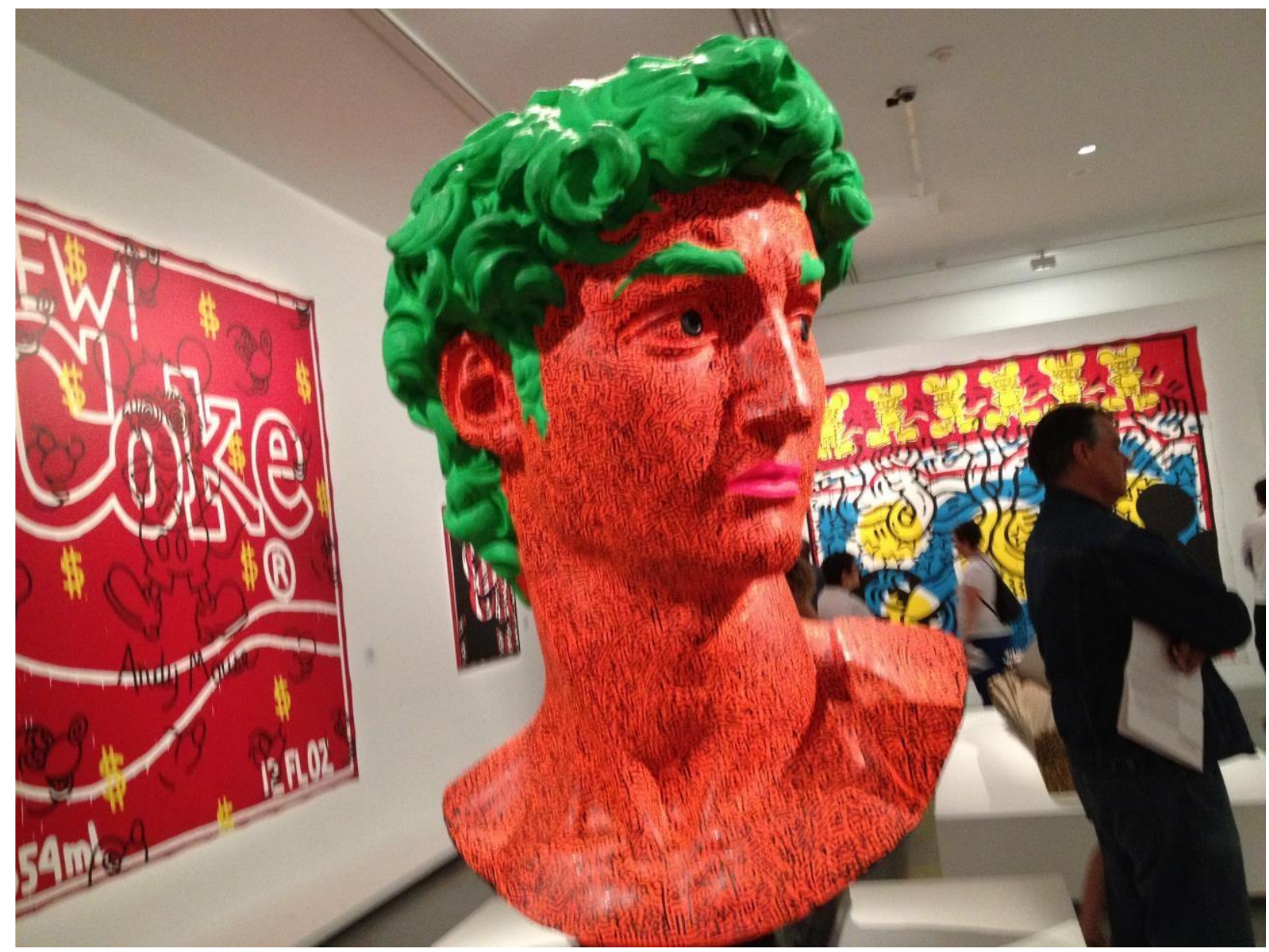

Source: Elena Siemens

French, it offers plenty of easy-to-read drawings. Addressing the distinction between street art and graffiti, the Graffiti Collective Faile states:

Street art is more about interacting with the audience on the street and the people, the masses. Graffiti isn't so much about connecting with the masses: it's about connecting with different crews, it's an internal language, it's a secret language. Most graffiti you can't even read, so it's really contained within the culture that understands it and does it. (Faile, qtd. in Lewisohn: 15)

Notwithstanding their differences, both street art and graffiti participate in mainstream culture. Lewisohn points out that mainstream culture both absorbs and fails to fully understand these unofficial genres: "you can see a tag on a model's T-Shirt featured on the cover of a high-fashion magazine, but have no idea what it actually represents or means" (Lewisohn 21). Art galleries and museums also tend to misinterpret the essence of street art and graffiti. Lewisohn quotes Blek le Rat, a pioneer graffiti artist from Paris, who states that at museums the viewer looks "at the shadow of the real thing" (Blek le Rat, qtd. in Lewisohn: 127). 
TranscUlturAl, vol. 6.1 (2014), 1-10.

http:// ejournals.library.ualberta.ca/index.php/TC

Attending a Keith Haring retrospective in Paris during the summer of 2013, I felt conflicted as well. Haring, who began with chalk drawings in NYC subway, appeared out of place within the museum's walls. However, there were some mitigating circumstances in this particular instance. The Museum of Modern Art of the City of Paris, in which the retrospective was held, occupies part of Palais de Tokyo, itself a contested territory. Constructed for the 1937 World Fair, Palais de Tokyo also houses the Site de Création (Site for Contemporary Creation), which, in turn, is governed by the French State. Palais de Tokyo's remote location in the $16^{\text {th }}$ arrondissement, far from the prestigious Louvre and other established museums, made viewing Haring more genuine. According to one of his associates, Haring himself saw the "world as almost a museum," and he wanted to bring his art to those millions of NYC subway commuters, who "didn't have the means or knowledge to go to museums" (Shafazi, qtd. in Lewisohn: 99).

Lewisohn concludes his book with a segment entitled "The End is No End" (2008: 153). Crediting street art and graffiti with a unique "mix of social activism, social outrage and creativity," he argues: "We now have a global audience for a truly global art form. Is this the end? No. We've only just begun" (Lewisohn 153). I bought Lewisohn's book at the de Young art museum in San Francisco, where it was displayed with other art books and souvenirs. A short walk from the Golden

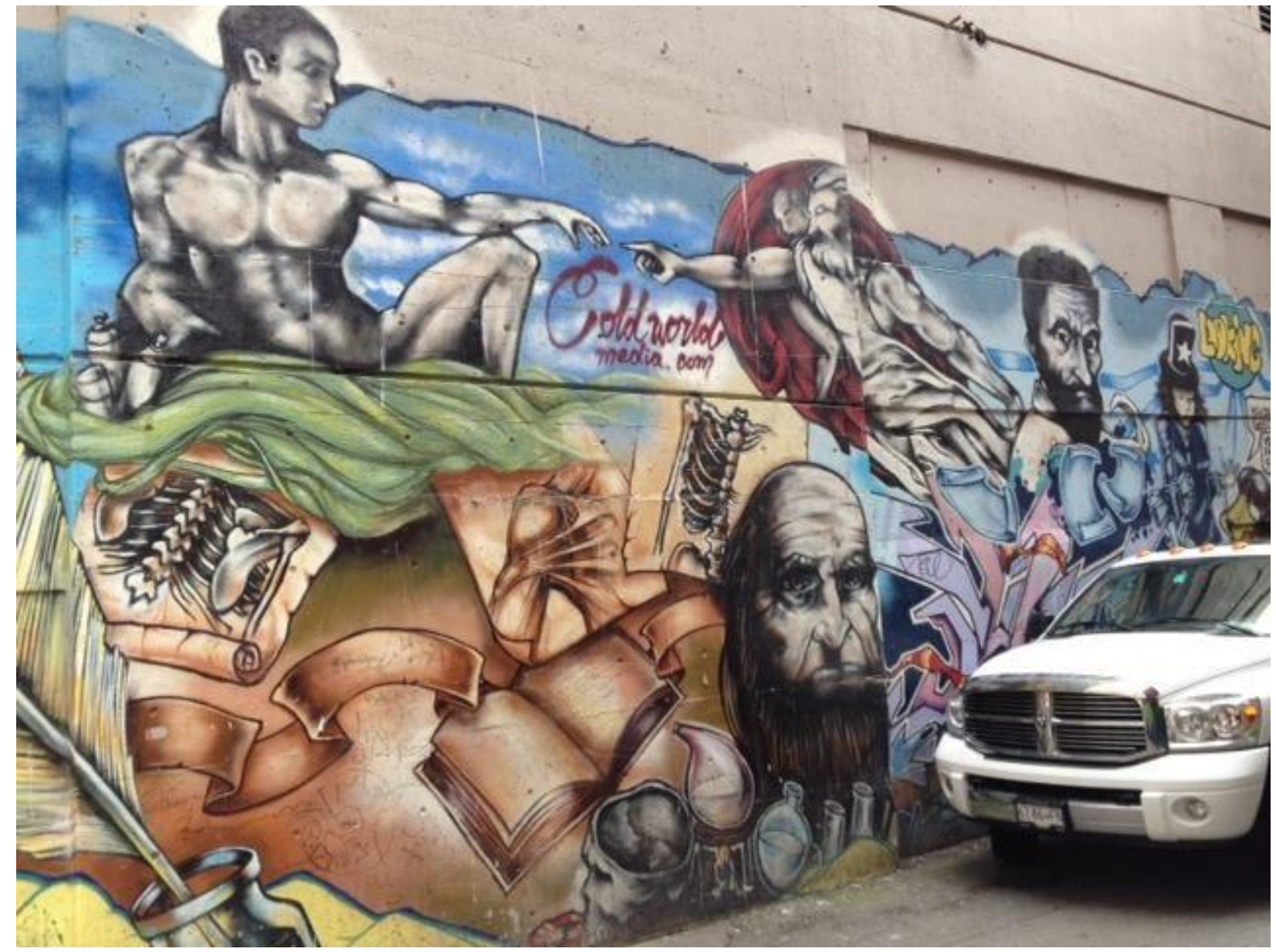

Source: Elena Siemens

This work is licensed under a Creative Commons Attribution 3.0 License 
Gate Park, where the de Young museum is situated, is the legendary Haight-Ashbury Street, described in tourist guides as "ground zero of the worldwide Flower-Power explosion of the 1960s," and still the city's "most scintillating and unconventional" quarter (Kennedy 100). Contrary to my expectations, I found few worthwhile examples of graffiti on Haight-Ashbury. My best photos from that visit were of the John Fluevog shoestore's whimsical façade. I had better luck in Vancouver several days later, where a back alley off Cordova Street contained walls of graffiti wonder.

I find myself torn between hope and disillusionment with regard to the future of graffiti. In his witty This Is Modern Art, Mathew Collings describes the fate of the Situationists as follows:

Situationist slogans really were on the walls during the Paris uprisings. Beneath the paving stonesthe beach! Live in free time! Then in no time the workers were back in the factories and the slogans were on the walls of the Museum of Modern Art in New York. (189)

Like live theatre, another highly vulnerable art, graffiti leaves behind no permanent record. Here today, gone tomorrow. But there are some advantages to this rise-and-fall mode of existence. Graffiti, also like live theatre, is always in the state of becoming, forever young. Between the two sites in Moscow and Paris, I am more optimistic about the latter. Its immediate proximity to Gainsbourg's former place of residence more or less guarantees its longevity. The Tsoi Wall's accidental location makes it considerably less likely to survive. The last time I photographed it, it looked completely abandoned, save for a couple of motorists inspecting their car parked near it.

\section{REFERENCES}

Banksy. Wall and Peace. London: The Random House Group, 2006.

Collings, Mathew. This is Modern Art. London: Weidenfeld \& Nicolson, 1999.

Kennedy, Jeffrey. Top 10 San Francisco. London: DK Publishing, 2014.

Lewisohn, Cedar. Street Art: The Graffiti Revolution, New York: Abrams, 2008.

Marcus, Grail. Lipstick Traces: The Secret History of the Twentieth Century. Harvard, MA: Harvard University Press, 1990.

Richardson, Dan. The Rough Guide to Moscow. London: Rough Guides Ltd., 2001.

Sutton, Isabelle. Unpublished translation.

Tsoi, Viktor. “Close the Door Behind Me.” Blood Type. http://russmus.net/song/7237\#2, accessed 18 August 2014.

- "Our Time, Our Turn.” Blood Type. http://community.muixmatch.com/lyrics/Our-

TimeOur-Turn, accessed 18 August 2014.

Whybrow, Nicolas. Art and the City. London: I.B. Tauris, 2011. 